\title{
Mantle Cell Lymphoma Presenting as a Subcutaneous Mass of the Right Leg
}

\author{
Drew A. Fajardo ${ }^{a}$ Joel France ${ }^{b}$ Bogna I. Targonska ${ }^{c-e}$ \\ H. Bobby Kahlon ${ }^{f}$ Max J. Coppes ${ }^{d, e}$ \\ aUniversity of Nevada Reno School of Medicine, Reno, NV, USA; ${ }^{b}$ Sierra Pathology \\ Associates, Reno, NV, USA; 'Reno Radiological Associates, Reno, NV, USA; \\ ${ }^{\mathrm{d}}$ Department of Pediatrics, University of Nevada Reno School of Medicine, Reno, NV, USA; \\ eRenown Children's Hospital, Reno, NV, USA; fFamily Medicine, Renown Medical Group, \\ Reno, NV, USA
}

\section{Keywords}

Lymphoma - Cancer · Mantle cell lymphoma - B-Cell · non-Hodgkin lymphoma - Extranodal sites · Cutaneous mantle cell lymphoma

\section{Abstract}

Mantle cell lymphoma (MCL) is a relatively rare B-cell non-Hodgkin lymphoma, typically presenting with extensive lymphadenopathy, bone marrow involvement, and splenomegaly. Extranodal sites can also be involved. We discuss a 73-year-old man whose MCL presented with a 6-month history of a subdermal mass of the right upper thigh and no systemic symptoms.

\author{
(c) 2020 The Author(s). \\ Published by S. Karger AG, Basel
}

\section{Introduction}

Mantle cell lymphoma (MCL) is a relatively rare malignancy of the lymphatic system [1]. MCL arises from malignant transformation of mature CD5-positive B-lymphocytes in the outer edge (mantle zone) of lymph node follicles. Characteristically, MCLs carry a t $(11 ; 14)$ (q13; 23) translocation resulting in overexpression of the cyclin D1 [1]. MCL accounts for approximately $6 \%$ of all non-Hodgkin lymphomas in the USA and about 7-9\% of lymphomas in Europe [1, 2]. It is considered as a distinct aggressive lymphoma subtype, occurs predominantly in males (2:1), and usually affects individuals in the fifth and sixth decades of life with the median age of presentation being just under 70 years. MCL usually presents with advancedstage (stage III or IV) disease. Consequently, patients often present with constitutional symptoms: weight loss, night sweats, persistent fevers, nausea, vomiting, and fatigue. For

Max J. Coppes

Renown Children's Hospital

1155 Mill Street

Reno, NV 89502 (USA)

mcoppes@renown.org 
those with massive node involvement in the gastrointestinal tract, symptoms at presentation often include abdominal pain, bloating, and a feeling of fullness.

Extranodal involvement at presentation is very common and most often involves bone marrow, peripheral blood, the gastrointestinal tract, Waldeyer's ring, and the liver. Extranodal disease as the primary presentation occurs in approximately $25 \%$ of cases. Presentation outside of these main extranodal sites is rare and includes salivary glands, skin (see Table 1), thyroid, orbit, breast, epidural space, pleura, and spleen. Presentation which involves the leg is extremely uncommon and, to the best of our knowledge, has always been associated with skin manifestation [3]. Here, we report the first case of MCL that presented with a subdermal mass of the leg.

\section{Case Report}

A 73-year-old Caucasian male with a family history of cancer (his father and brother had prostate cancer and his sister had breast cancer) presented to his family physician with a 6-month history of a mass located medially on his right upper thigh. There was no history of trauma, the mass was nontender, and it had not grown in size. There were no systemic symptoms including fever chills, night sweating, or unintentional weight loss. He denied any nausea, vomiting, or generalized malaise. He had no prior history of smoking or tobacco product use, denied the use of alcohol, and had no history of being immunocompromised.

Physical examination revealed a subcutaneous firm, nonmobile, not warm, irregular mass of approximately $4 \mathrm{~cm}$ on the patient's right upper outer thigh with no associated inguinal lymphadenopathy. The patient's abdomen was soft, nontender, with no masses, hepatomegaly, or splenomegaly. The patient's afflicted leg showed no signs of muscle weakness, and the range of motion was normal.

A complete blood count (CBC) demonstrated a WBC of 7.9 K/ $\mu \mathrm{L}$ (normal 4.8-10.8) with a normal differential, $\mathrm{Hb} 5.84 \mathrm{M} / \mu \mathrm{L}$ (normal 4.70-6.10), Ht 50.7\% (normal 42.0-52.0), and platelet count $243 \mathrm{~K} / \mu \mathrm{L}$ (normal 164-446). His electrolytes, liver and renal functions were normal. An ultrasound of the right leg was performed and showed a vascularized heterogeneous mass measuring $5.9 \times 3.8 \times 1.3 \mathrm{~cm}$ within the subcutaneous soft tissues, consistent with either a primary muscular or metastatic tumor.

A subsequent magnetic resonance imaging (MRI) with contrast of the right lower extremity (Fig. 1) demonstrated a $5.4 \times 3.4 \times 1.5 \mathrm{~cm}$ mass which was noted to be T2 hyperintense, T1 slightly hyperintense to muscle, and which avidly enhanced in a uniform fashion following contrast administration. The mass was found to be superficial to the rectus femoris muscle with no signs of muscular invasion. The remainder of the thigh was normal on imaging. Several small bilateral inguinal lymph nodes were noted, all within normal limits. At this point, the imaging findings were still primarily concerning for a soft tissue sarcoma or metastasis.

A contrast-enhanced computed tomography (CT) of the chest, abdomen, and pelvis revealed bilateral axillary lymphadenopathy. The liver, pancreas, adrenal glands, and kidneys were unremarkable. Multiple enlarged gastro-hepatic lymph nodes, the largest measuring 5 $\times 3 \mathrm{~cm}$ in size, were visualized. Multiple mildly prominent retroperitoneal lymph nodes were also present, the largest measuring up to $10 \mathrm{~mm}$ in the short axis dimension. Based on these findings, the differential diagnosis included metastatic adenopathy and lymphoma.

Microscopic examination of a right thigh biopsy demonstrated sheets of intermediatesized lymphocytes with somewhat dispersed chromatin, occasional inconspicuous nucleoli, irregular nuclear contours, and scant amphophilic cytoplasm (Fig. 2). Brisk mitotic activity was noted. The neoplastic cells were strongly and diffusely positive for CD20, CD5, and cyclin 


\section{Case Reports in Oncology}

Case Rep Oncol 2020;13:774-782

\begin{tabular}{l|l}
\hline DOI: $10.1159 / 000507921$ & ( 2020 The Author(s). Published by S. Karger AG, Basel
\end{tabular} www.karger.com/cro

Fajardo et al.: Mantle Cell Lymphoma Presenting as a Subcutaneous Mass of the Right Leg

Table 1. Clinical features of patients with MCL skin presentation

\begin{tabular}{|c|c|c|c|c|c|c|c|c|c|}
\hline $\begin{array}{l}\text { First author } \\
\text { [ref.] }\end{array}$ & Patient & $\begin{array}{l}\text { Age, } \\
\text { years }\end{array}$ & Gender & Site/lesion & $\begin{array}{l}\text { Skin as } \\
\text { initial presen- } \\
\text { tation }\end{array}$ & $\begin{array}{l}\text { Other } \\
\text { sites at } \\
\text { diagnosis }\end{array}$ & $\begin{array}{l}\text { Stage at initial } \\
\text { diagnosis }\end{array}$ & Initial treatment & Outcome \\
\hline \multicolumn{10}{|l|}{ A } \\
\hline \multirow[t]{2}{*}{ Geerts [7] } & 1 & 73 & $\mathrm{~F}$ & Scalp & + & + & $4 \mathrm{~B}$ & CLB + PRED & $\begin{array}{l}\text { Relapse at } 14 \text { months and died } 4 \\
\text { months later }\end{array}$ \\
\hline & 2 & 65 & $\mathrm{~F}$ & Back, chest, arm & + & + & $4 \mathrm{~B}$ & $\mathrm{COP}+\mathrm{CHOP}$ & $\begin{array}{l}\text { Relapsed at } 11 \text { months, died } 11 \\
\text { months later }\end{array}$ \\
\hline \multirow[t]{4}{*}{ Bertero [6] } & 3 & 51 & M & Breast & + & + & $\begin{array}{l}\text { Late stage } \\
(3 \text { or } 4)\end{array}$ & $\begin{array}{l}\text { Multiple } \\
\text { (COP-CHOP-XRT) }\end{array}$ & $\begin{array}{l}\text { Multiple relapses, favorable } \\
\text { response to treatments, alive and } \\
\text { in CR after } 17 \text { years }\end{array}$ \\
\hline & 4 & 78 & M & Breast and back & + & - & 1 & Observation & Died after 3 years, unrelated cause \\
\hline & 5 & 43 & M & $\begin{array}{l}\text { Back, face, sternum, } \\
\text { arms }\end{array}$ & + & + & Stage 2 or 3 & $\mathrm{COP}+\mathrm{CHOP}$ & Obtained CR, unknown status \\
\hline & 6 & 22 & M & Chest & + & - & 1 & Patient refused therapy & Unknown \\
\hline Moody [9] & 7 & 47 & M & Earlobe & + & + & $4 \mathrm{~B}$ & CHOP & Alive with disease at 3 years \\
\hline Marti [8] & 8 & 61 & $\mathrm{~F}$ & Abdominal & + & + & 4 & CHOP & $\begin{array}{l}\text { Initial CR, relapsed and died } 15 \\
\text { months after diagnosis }\end{array}$ \\
\hline \multirow[t]{4}{*}{ Sen [11] } & 9 & 85 & M & Leg/rash & + & + & $4 \mathrm{~B}$ & CHOP & Died 20 months after diagnosis \\
\hline & 10 & 76 & M & Thigh/nodule & + & - & 1 & Hyper-CVAD & $\begin{array}{l}\text { Relapsed, alive with disease at } 30 \\
\text { months }\end{array}$ \\
\hline & 11 & 56 & M & Chest/nodules & + & + & $4 \mathrm{~A}$ & Hyper-CVAD & Alive at 21 months \\
\hline & 12 & 57 & M & Legs/rash & + & + & $4 \mathrm{~B}$ & Hyper-CVXD & Died 9 months after diagnosis \\
\hline \multirow[t]{2}{*}{ Dubus $[10]$} & 13 & 56 & M & Breast, back & + & + & $4 \mathrm{~A}$ & $\begin{array}{l}\text { CHOP, DEXA-BEAM + } \\
\text { allograft }\end{array}$ & $\begin{array}{l}\mathrm{CR} \text { at } 1 \text { year, died of meningeal } \\
\text { hemorrhage }\end{array}$ \\
\hline & 14 & 89 & M & $\begin{array}{l}\text { Breast, back, } \\
\text { abdomen }\end{array}$ & + & + & $4 \mathrm{~B}$ & None & $\begin{array}{l}\text { Died of cerebral and cardiovascular } \\
\text { failure on day } 5\end{array}$ \\
\hline Motegi [12] & 15 & 62 & M & $\begin{array}{l}\text { Back, upper } \\
\text { extremities }\end{array}$ & + & + & 4 & $\begin{array}{l}\text { Hyper-CVAD + MTX/ } \\
\text { Ara-C + RTX }\end{array}$ & CR of skin lesions at 4 months \\
\hline Estrozi [13] & 16 & 72 & M & Temporal (head) & + & - & 1 & Local XRT & Alive in CR at 6 months \\
\hline Canpolat [14] & 17 & 49 & $\mathrm{~F}$ & $\begin{array}{l}\text { Face, shoulders, } \\
\text { back, chest }\end{array}$ & + & + & $4 \mathrm{~B}$ & Intense chemotherapy & Died at 4 months \\
\hline Lynch [17] & 18 & 83 & M & Thighs & + & Unclear & Likely 1 or 2 & RTX, VMP & $\begin{array}{l}\text { Died at } 2 \text { months, disseminated } \\
\text { herpes zoster }\end{array}$ \\
\hline Zattra [16] & 19 & 77 & M & Multiple body areas & + & - & 1 & VP16, PRED & Alive at 28 months with almost CR \\
\hline Cao [18] & 20 & 53 & M & Legs & + & + & $4 \mathrm{~A}$ & Chemotherapy & Died at 5 weeks \\
\hline Cesinaro [19] & 21 & 75 & $\mathrm{~F}$ & Leg & + & - & 1 & Local XRT & $\begin{array}{l}\text { Relapsed at } 14 \text { months, died at } 40 \\
\text { months }\end{array}$ \\
\hline \multirow[t]{6}{*}{ Wehkamp [3] } & 22 & 68 & M & Both legs & + & + & $4 \mathrm{~A}$ & RTX-CHOP & Dead at 62 months \\
\hline & 23 & 74 & M & Leg & + & - & 1 & Surgery & Alive at 5 months \\
\hline & 24 & 82 & M & Leg & + & & $4 \mathrm{~A}$ & Surgery & Dead at 26 months \\
\hline & 25 & 50 & M & Scalp & + & + & 3 & RTX-CHOP & Dead at 107 months \\
\hline & 26 & 84 & M & Arm & + & + & 4 & RTX-bendamustine & Alive at 11 months \\
\hline & 27 & 70 & M & Back & + & + & 4 & No therapy & Alive at 9 months \\
\hline Hrgovic [20] & 28 & 55 & $\mathrm{~F}$ & Face & + & + & $4 \mathrm{~A}$ & RTX-CHOP, IT MTX & $\begin{array}{l}\text { Relapse at } 16 \text { months, intensive } \\
\text { treatment including auto-PBSTC, } \\
\text { alive at } 4 \text { years }\end{array}$ \\
\hline $\begin{array}{l}\text { Cherukuri } \\
{[21]}\end{array}$ & 29 & 61 & M & Back & + & + & $4 \mathrm{~A}$ & Unknown & Unknown \\
\hline
\end{tabular}




\section{Case Reports in Oncology}

\begin{tabular}{l|l}
\hline Case Rep Oncol 2020;13:774-782 \\
\hline DOI: 10.1159/000507921 & $\begin{array}{l}\text { ○ 2020 The Author(s). Published by S. Karger AG, Basel } \\
\text { www.karger.com/cro }\end{array}$ \\
\hline
\end{tabular}

Fajardo et al.: Mantle Cell Lymphoma Presenting as a Subcutaneous Mass of the Right Leg

Table 1 (continued)

\begin{tabular}{|c|c|c|c|c|c|c|c|c|c|}
\hline $\begin{array}{l}\text { First author } \\
\text { [ref.] }\end{array}$ & Patient & $\begin{array}{l}\text { Age, } \\
\text { years }\end{array}$ & Gender & Site/lesion & $\begin{array}{l}\text { Skin as } \\
\text { initial presen- } \\
\text { tation }\end{array}$ & $\begin{array}{l}\text { Other } \\
\text { sites at } \\
\text { diagnosis }\end{array}$ & $\begin{array}{l}\text { Stage at initial } \\
\text { diagnosis }\end{array}$ & Initial treatment & Outcome \\
\hline Our patient & 30 & 73 & M & Thigh & + & + & $4 \mathrm{~A}$ & $\begin{array}{l}\text { R-CHOP/R- DHAOX, } \\
\text { R-BEAM + PBSCT }\end{array}$ & Alive at 12 months \\
\hline \multicolumn{10}{|l|}{ B } \\
\hline Ellison [5] & 29 & 66 & M & Temporal & - & + & $4 \mathrm{~B}$ & & \\
\hline Sen [11] & 30 & 61 & M & $\begin{array}{l}\text { Flank, back, thigh / } \\
\text { plaques }\end{array}$ & - & + & $4 \mathrm{~B}$ & & \\
\hline Dubus [10] & 31 & 72 & M & Face, breast, arm & - & + & 4 & & \\
\hline Ishibashi [15] & 32 & 68 & M & Thigh, arm & - & + & 4 & & \\
\hline \multirow[t]{6}{*}{ Wehkamp [3] } & 33 & 85 & M & Thigh & - & & $1 \mathrm{E}$ & & \\
\hline & 34 & NK & M & Back & - & NK & NK & & \\
\hline & 35 & 76 & M & Skin NK & - & NK & NK & & \\
\hline & 36 & 55 & M & Leg & - & + & 4 & & \\
\hline & 37 & 77 & M & Both legs & - & + & 4 & & \\
\hline & 38 & 69 & M & Leg & - & + & $4 \mathrm{~B}$ & & \\
\hline \multicolumn{10}{|l|}{ C } \\
\hline \multirow[t]{2}{*}{ Wehkamp [3] } & 39 & NK & M & Shoulder & NK & NK & NK & & \\
\hline & 40 & 45 & $\mathrm{M}$ & NK & NK & + & 4 & & \\
\hline
\end{tabular}

F, female; M, male; CLB, chlorambucil; PRED, prednisolone; CTX, cyclophosphamide; DOX, doxorubicin; VCR, vincristine; BCNU, carmustine; VP16, etoposide; Ara-C cytarabine; RTX, rituximab; VMP, bortezomib; MTX, methotrexate; IT, intrathecal; XRT, radiotherapy; CR, complete remission; PBSCT, peripheral blood stem cell transplant; COP, CTX + VCR + PRED; CHOP, CTX + DOX + VCR + PRED; hyper-CVXD, CTX + liposomal daunorubicin + VCR + dexamethasone; hyper-CVAD, CTX + VCR + DOX + DEX; DEXA-BEAM, DEX + BCNU + VP16 + Ara-C + melphalan; R-CHOP, RTX +DEX + Ara-C + oxiplatine; R-DHAOX, RTX + DEX + Ara-C + cisplatin; R-BEAM, RTX + BCNU + VP16 + Ara-C + melphalan; NK, not known.
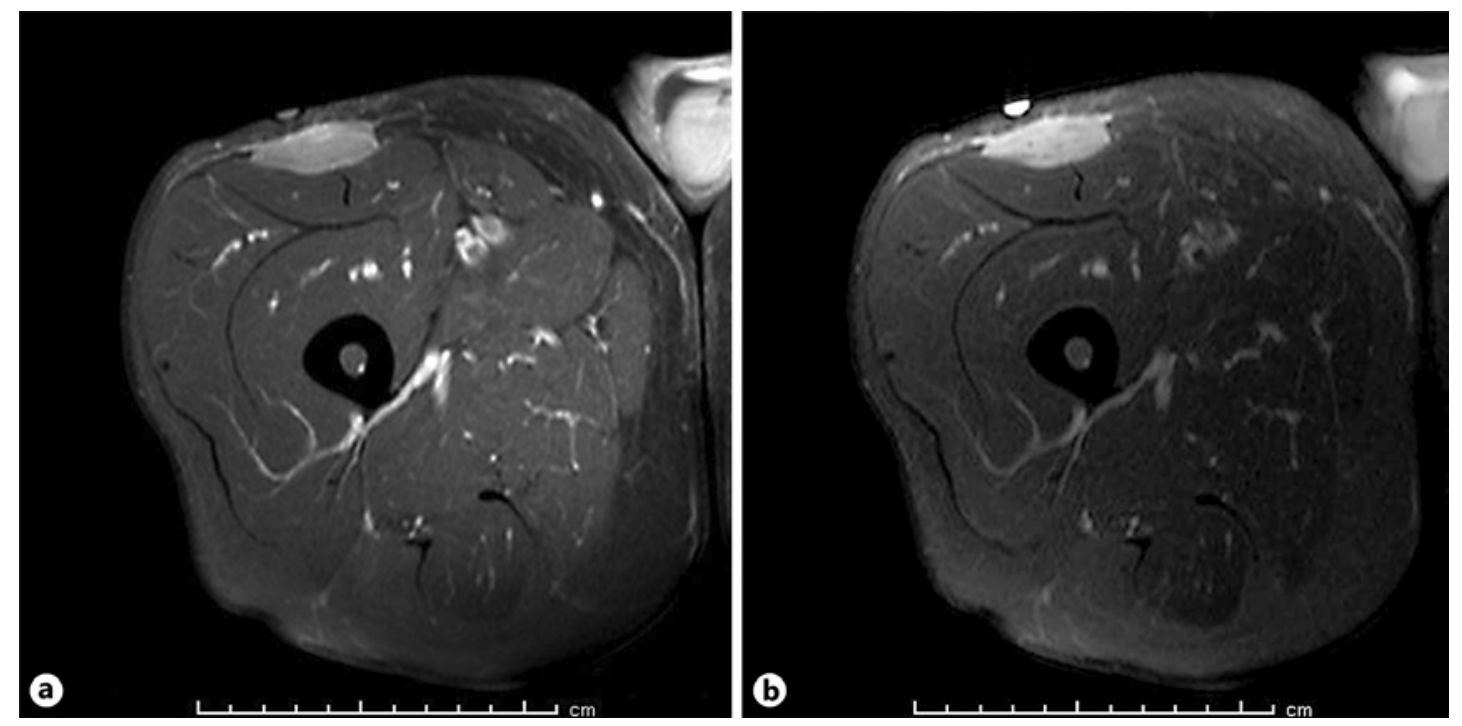

Fig. 1. MRI of the lower extremity demonstrates a subcutaneous mass which is well defined and T2 hyperintense on T2-weighted fat saturated images (a) and which avidly enhances following contrast administration (b). 


\section{Case Reports in Oncology}

\begin{tabular}{l|l}
\hline Case Rep Oncol 2020;13:774-782 \\
\hline DOI: 10.1159/000507921 & $\begin{array}{l}\text { @ 2020 The Author(s). Published by S. Karger AG, Basel } \\
\text { www.karger.com/cro }\end{array}$ \\
\hline
\end{tabular}

Fajardo et al.: Mantle Cell Lymphoma Presenting as a Subcutaneous Mass of the Right Leg
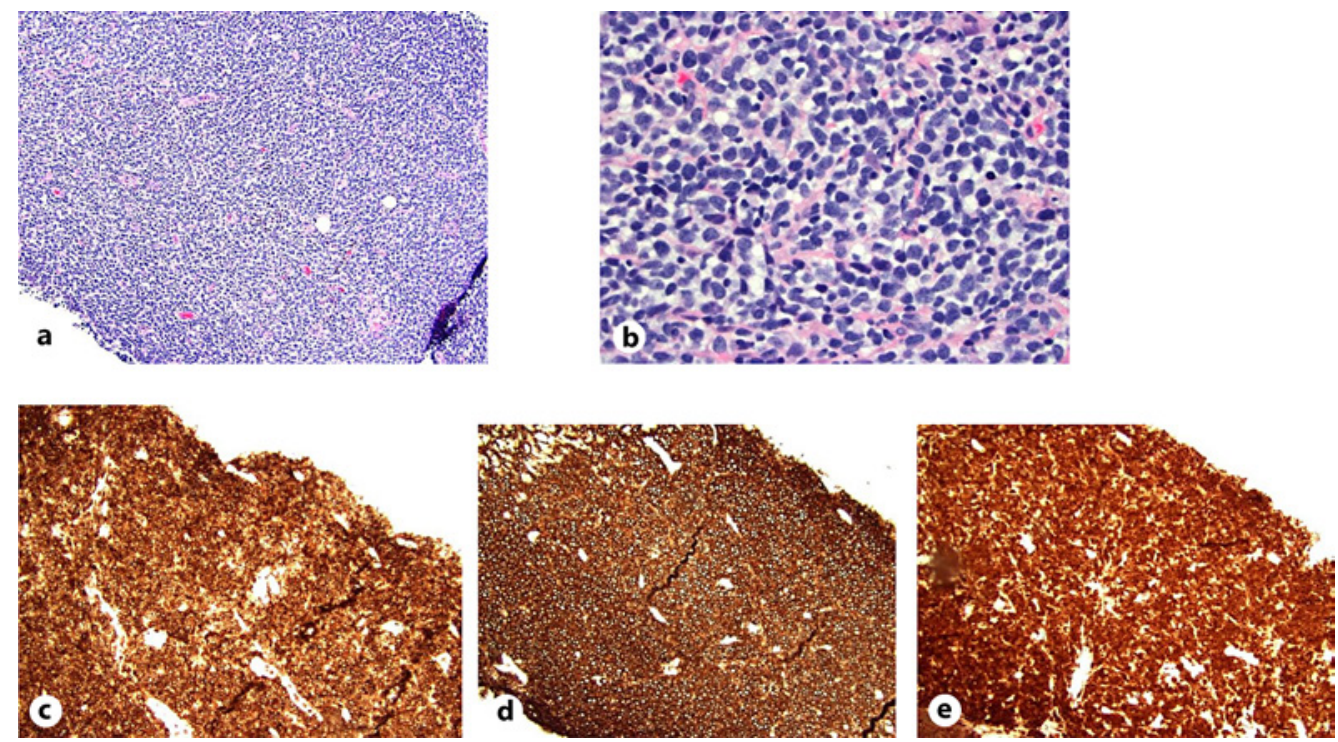

Fig. 2. Histopathology of MCL in the subcutaneous tissue. a, b Dense infiltrate of small- to intermediate-sized atypical lymphocytes with irregular nuclear contours, somewhat dispersed chromatin, inconspicuous nucleoli, and scant amphophilic cytoplasm (hematoxylin and eosin, $\times 100$ and $\times 400$ ). The neoplastic cells are strongly and diffusely positive for CD5 (c), CD20 (d), and cyclin D1 (e) (immunoperoxidase, ×100).
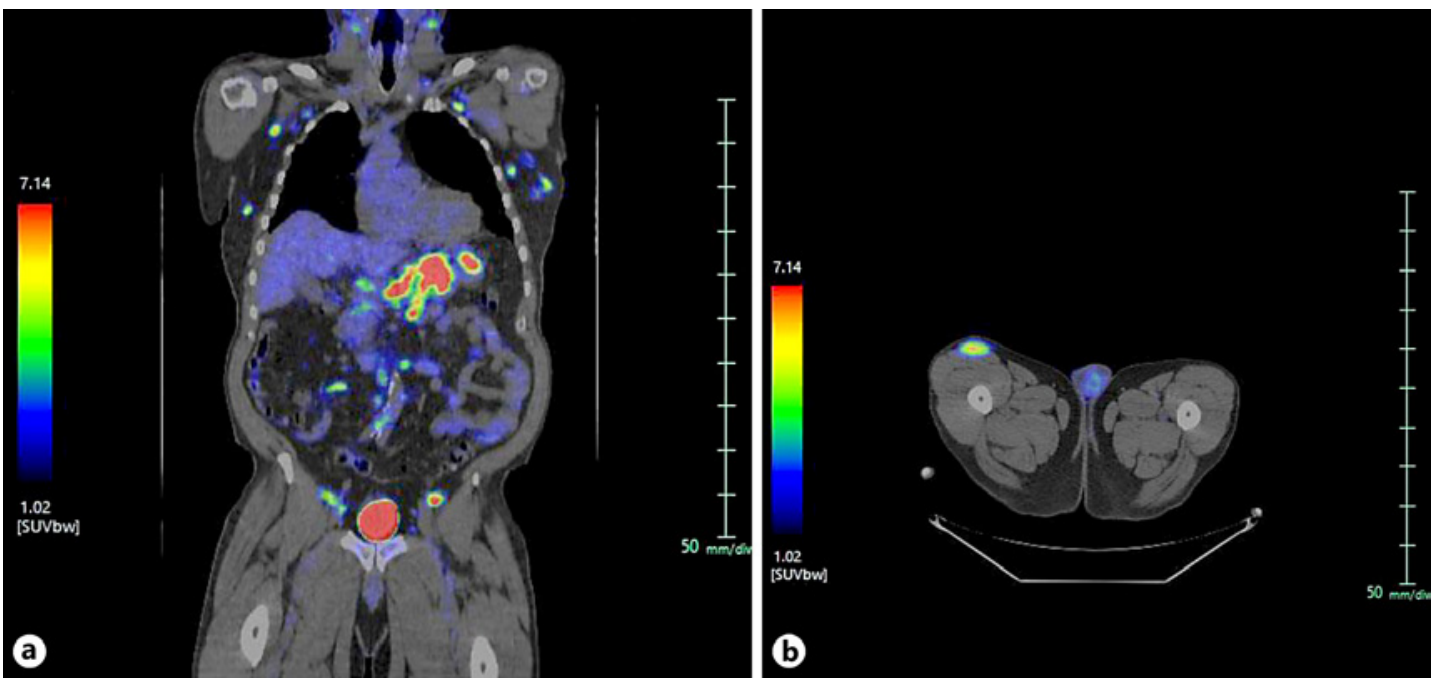

Fig. 3. PET/CT imaging demonstrating FDG uptake within cervical, axillary, gastro-hepatic, retroperitoneal, and pelvic lymph nodes (a). Uptake is also seen within the subcutaneous right thigh mass compatible with lymphoma (b).

D1, positive for BCL2, and negative for CD3, CD10, CD23, and BCL6. The proliferation index was estimated at $>95 \%$ based upon Ki-67 expression. A subsequent biopsy of an enlarged celiac lymph node showed similar morphology and demonstrated kappa-restricted B cells strongly positive for CD20 and CD5 by flow cytometry. These results were consistent with MCL. TP53 sequencing was not performed. 
A post-biopsy fluorodeoxyglucose-positron emission tomography (FDG-PET) scan (Fig. 3) revealed abnormal uptake within lymphadenopathy in the neck, bilateral axilla, mesenteric, retroperitoneal, and bilateral pelvic regions. There was also diffuse uptake in the spleen and abnormal uptake in the known right anterior thigh lesion. This is consistent with MCL involvement.

A bone marrow aspirate demonstrated abundant bone marrow particles for review. Numerous megakaryocytes were noted, most demonstrating normal lobulated nuclei. There was trilineage hematopoiesis with maturation and progression of the myeloid series through the segmented neutrophil. No significant dysgranulopoiesis was seen. There was no morphologic increase in blast cells. Numerous erythroid precursors were noted demonstrating normoblastic maturation. No significant dyserythropoiesis was seen. Scattered small- to intermediate-sized lymphocytes were noted and did not appear to be increased in quantity. Occasional plasma cells were seen, not increased in quantity. Flow cytometry showed 2 small monoclonal B-cell populations, one with CD5-positive B cells ( $2 \%$ of lymphoid cells) and a separate one with CD10-positive B cells (5\% of lymphoid cells) both showing kappa light chain restriction. CD34+ cells (2.4\% of total cells) were not increased. In conclusion, the bone marrow aspirate presented no morphologic or immunohistochemical evidence for bone marrow involvement by MCL. A bone marrow biopsy demonstrated cellularity averaging approximately 50\% with areas of intramedullary hemorrhage. Scattered megakaryocytes were adequate in quantity with most appearing to demonstrate normal lobulated nuclei. Trilineage hematopoiesis with maturation was present. There appears to be a mild erythroid hyperplasia. The myeloid to erythroid ratio appears to be decreased and was estimated at approximately 1:1. There was no obvious increase in blast cells. There was no obvious increase in plasma cells. No lymphoid aggregates or atypical lymphocytes were seen. No morphologic evidence for bone marrow involvement by MCL was seen.

The patient went to UC Davis' Comprehensive Cancer Center for therapy that consisted of R-CHOP (rituximab plus cyclophosphamide, doxorubicin, vincristine, and prednisone) alternating with R-DHAOx (rituximab plus dexamethasone, high-dose cytarabine, and oxaliplatin), a slight modification of standard R-CHOP alternating with R-DHAP (rituximab plus dexamethasone, high-dose cytarabine, and cisplatin) as cisplatin was substituted with oxaliplatin due to the patient's age [4]. After 6 courses of chemotherapy, a PET-CT showed complete full metabolic remission. He proceeded to receive high-dose chemotherapy consisting of R-BEAM (Rituxan, BCNU, etoposide, cytosine arabinoside, and melphalan) followed by autologous stem cell transplantation/rescue as consolidation. At present, he is alive with no evidence of disease 12 months following diagnosis.

\section{Discussion}

While rare, MCL, which typically presents as advanced-stage disease, is prevalent enough to have a common and therefore recognizable presentation. Most patients will present with multiple enlarged lymph nodes and constitutional symptoms. However, in a few instances the initial presentation will be primarily extranodal, not involving the commonly reported (bone marrow, peripheral blood, gastrointestinal tract, Waldeyer's ring, and/or liver) extranodal sites. Since a full picture of MCL relies on larger series of patient as well as on distinct case reports, we believe that our case further broadens our understanding of how MCL can present clinically.

Over the past few decades, numerous reports have highlighted that MCL can present, albeit infrequently, in the skin. An extensive review of the English literature revealed 42 cases $[3,5-21]$ (Table 1), including our patient, with MCL skin presentation. Of them, 30 patients

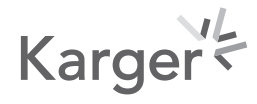


(71\%) actually presented to their physician with skin anomalies that led to the diagnosis (section A of Table 1), in 10 patients skin involvement either followed other organ involvement or was found at initial diagnosis but was not the presenting symptom (section B of Table 1), while in 2 cases (section $\mathrm{C}$ of Table 1) this feature was not known (these 2 cases are part of a retrospective pathology registry review [3]).

The mean age of the 30 patients presenting with skin involvement was 67 years (range $22-89)$, and all but $6(80 \%)$ were male; this is similar to what has been reported for patients with MCL in general [2]. It would seem that any area of the skin can be affected, including the scalp [7] and earlobes [9]. Also, the presentation of skin involvement varies greatly and is not restricted to nodules, but can present as erythematous (infiltrated) plaques, a macular rash, papules, petechiae, ecchymosis, or even a subcutaneous mass. This observation suggests that any skin lesion in an older male patient, who also has systemic (B) symptoms, should be biopsied. Moreover, for patients presenting with a skin lesion of the leg, consideration should be given to primary cutaneous B-cell lymphoma, pcDLBCL-lt, which in fact shares many of the immunohistochemical features of MCL. Using the guidelines identified in the National Comprehensive Cancer Network (NCCN) version 1.2020 is paramount in arriving at the correct diagnosis. Adequate immunophenotyping includes CD5, CD20, CD43, CD23, CD10, and cyclin D. The latter is pathognomonic for MCL and allows distinguishing these 2 entities. Cell surface marker analysis by flow cytometry with peripheral blood and/ or tumor tissue should also be performed for kappa/lambda, CD19, CD20, CD5, CD23, and CD10. We did not perform TP53 sequencing but recommend this to be done routinely, especially for those patients with an expected aggressive clinical course or if transplantation is considered upfront at diagnosis. Additional testing that can be of use includes LEF1 expression, SOX11 or IGHV sequencing, karyotyping or FISH to look for $\mathrm{t}(11 ; 14), \mathrm{t}(14 ; 18)$, and cell surface marker analysis by flow cytometry with peripheral blood and/or biopsy specimen for CD200.

Based on the occasionally subtle skin manifestations of MCL, that is, cases 1 and 3, we suggest that all patients with MCL would benefit from a detailed skin exam at initial presentation, to ensure appropriate staging.

With regard to staging, we reviewed all case reports and recorded staging if documented or, alternatively if possible, assigned a stage based on the data provided (see Table 1). Based on this, 7 patients presented with stage 1 disease, 1 with stage 3 disease, and 19 with stage 4 disease, while for the remaining 3 patients a definitive stage could not be determined. One with late-stage disease had stage 3 or 4 disease (as determined by us), one had stage 2 or 3 disease, and the last one had either stage 1 or 2 disease. This means that of those for whom staging was clear $(n=27), 74 \%$ presented with advanced-stage disease, similar to what has been reported for MCL in general.

In terms of treatment, data available from the cases presented do not suggest that patients presenting with cutaneous MCL should be treated any different from others with MCL. In general, patients with advanced-stage disease benefit from adjuvant chemotherapy. Since MCL is clinically heterogeneous, treatment should be adjusted to the patient's age and any prevalent comorbidities. Excellent suggestions for consideration were recently provided by Fakhri and Kahl [22].

In summary, MCL is relatively rare but usually presents with typical symptoms associated with lymphoma. Patients primarily presenting with either cutaneous or subcutaneous lesions are exceedingly rare, but they do form part of the clinical presentation of MCL. These lesions can occasionally be present for months, as in our patient. Immediate adequate investigation is paramount to provide the patient with the best possible outcome. 


\section{Case Reports in Oncology}

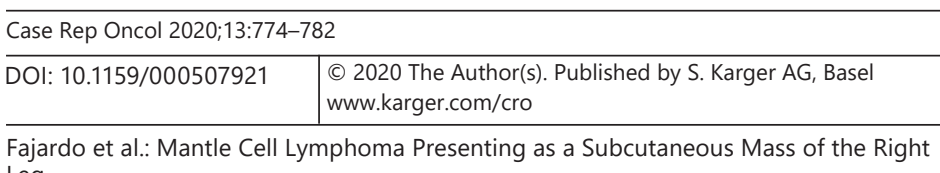

Leg

\section{Statement of Ethics}

Witten consent to publish all data presented in this manuscript was obtained from the patient.

\section{Conflict of Interest Statement}

The authors declare to have no conflict of interest. Financial support (all based on employment) is provided under "Funding Sources."

\section{Funding Sources}

Drew A. Fajardo is a medical student and has no funding sources to disclose.

Joel France is employed by Sierra Pathology Associates, Reno, NV.

Bogna I. Targonska is employed by Reno Radiological Associates, Reno, NV.

$\mathrm{H}$. Bobby Kahlon is employed by Renown Medical Group in Reno, NV.

Max J. Coppes is employed by the University of Nevada Reno School of Medicine and his salary is in part supported (through the University) by Renown Health and the Nell J. Redfield Foundation (Reno, NV). In 2020, he received USD 2,000 from Penn State University for a formal review of their pediatric oncology program. As a Section Editor of Pediatric Research, he receives a stipend of USD 1,000 per year. As a consultant he received the following stipends from Leo Pharma: USD 2,450 in 2019; USD 3,400 in 2018; and USD 20,050 in 2017. From 2017 to 2019, he received a total of USD 800 from SilverSummit Healthplan for his work as a committee member of their Quality Improvement Committee. In 2008, he received an honorarium of USD 500 for editing one of the Pediatric Clinics of North America.

\section{Author Contributions}

Drew A. Fajardo identified the patient as of interest, collected all relevant information, participated in the literature search, wrote the first draft, and edited subsequent drafts. He approved the finalized manuscript.

Joel France collected and interpreted all relevant laboratory information (he was not the primary pathologist for all studies performed), participated in the literature search, specifically with regard to immunohistochemistry, edited drafts, and approved the finalized manuscript.

Bogna I. Targonska collected and interpreted all relevant imaging information (she was not the radiologist on any of the imaging studies performed), edited drafts, and approved the finalized manuscript.

H. Bobby Kahlon is the patient's primary care physician. He helped Drew A. Fajardo obtain all clinical information and obtained consent from the patient to publish a manuscript that includes medical information of the patient. He approved the finalized manuscript.

Max J. Coppes actively mentored Drew A. Fajardo in all aspects of the manuscript, connecting him with the right pathologist and radiologist that helped put the manuscript together. He reviewed the drafts in detail, helped to expand literature search, and helped selecting the right Figures and Table. He approved the finalized manuscript and is the corresponding author.

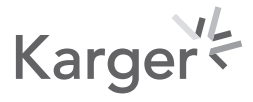


Fajardo et al.: Mantle Cell Lymphoma Presenting as a Subcutaneous Mass of the Right Leg

\section{References}

1 Vose JM. Mantle cell lymphoma: 2017 update on diagnosis, risk-stratification, and clinical management. Am J Hematol. 2017 Aug;92(8):806-13.

2 Zhou Y, Wang H, Fang W, Romaguer JE, Zhang Y, Delasalle KB, et al. Incidence trends of mantle cell lymphoma in the United States between 1992 and 2004. Cancer. 2008 Aug 15;113(4):791-8.

3 Wehkamp U, Pott C, Unterhalt M, Koch K, Weichenthal M, Klapper W, et al. Skin involvement of mantle cell lymphoma may mimic primary cutaneous diffuse large B-cell lymphoma, leg type. Am J Surg Pathol. 2015 Aug; 39(8):1093-101.

4 Hermine O, Hoster E, Walewski J, Bosly A, Stilgenbauer S, Thieblemont C, et al. Addition of high-dose cytarabine to immunochemotherapy before autologous stem-cell transplantation in patients aged 65 years or younger with mantle cell lymphoma (MCL Younger): a randomised, open-label, phase 3 trial of the European Mantle Cell Lymphoma Network. Lancet. 2016 Aug 6;388(10044):565-75.

5 Ellison DJ, Turner RR, Van Antwerp R, Martin SE, Nathwani BN. High-grade mantle zone lymphoma. Cancer. 1987 Dec 1;60(11):2717-20.

6 Bertero M, Novelli M, Fierro MT, Bernengo MG. Mantle zone lymphoma: an immunohistologic study of skin lesions. J Am Acad Dermatol. 1994 Jan;30(1):23-30.

7 Geerts ML, Busschots AM. Mantle-cell lymphomas of the skin. Dermatol Clin. 1994 Apr;12(2):409-17.

8 Martí RM, Campo E, Bosch F, Palou J, Estrach T. Cutaneous lymphocyte-associated antigen (CLA) expression in a lymphoblastoid mantle cell lymphoma presenting with skin lesions. Comparison with other clinicopathologic presentations of mantle cell lymphoma. J Cutan Pathol. 2001 May;28(5):256-64.

9 Moody BR, Bartlett NL, George DW, Price CR, Breer WA, Rothschild Y, et al. Cyclin D1 as an aid in the diagnosis of mantle cell lymphoma in skin biopsies: a case report. Am J Dermatopathol. 2001 Oct;23(5):470-6.

10 Dubus P, Young P, Beylot-Barry M, Belaud-Rotureau MA, Courville P, Vergier B, et al. Value of interphase FISH for the diagnosis of $\mathrm{t}(11: 14)$ (q13; q32) on skin lesions of mantle cell lymphoma. Am J Clin Pathol. 2002 Dec; 118(6):832-41.

11 Sen F, Medeiros LJ, Lu D, Jones D, Lai R, Katz R, et al. Mantle cell lymphoma involving skin: cutaneous lesions may be the first manifestation of disease and tumors often have blastoid cytologic features. Am J Surg Pathol. 2002 Oct;26(10):1312-8.

12 Motegi S, Okada E, Nagai Y, Tamura A, Ishikawa O. Skin manifestation of mantle cell lymphoma. Eur J Dermatol. 2006 Jul-Aug;16(4):435-8.

13 Estrozi B, Sanches JA Jr, Varela PC, Bacchi CE. Primary cutaneous blastoid mantle cell lymphoma-case report. Am J Dermatopathol. 2009 Jun;31(4):398-400.

14 Canpolat F, Taş E, Albayrak Sönmez A, Oktay M, Eskioğlu F, Alper M. Cutaneous presentation of mantle cell lymphoma. Acta Derm Venereol. 2010 Sep;90(5):548-50.

15 Ishibashi M, Yamamoto K, Kudo S, Chen KR. Mantle cell lymphoma with skin invasion characterized by the common variant in the subcutis and blastoid transformation in the overlying dermis. Am J Dermatopathol. 2010 Apr;32(2):180-2.

16 Zattra E, Zambello R, Marino F, Bordignon M, Alaibac M. Primary cutaneous mantle cell lymphoma. Acta Derm Venereol. 2011 Jun;91(4):474-5.

17 Lynch DW, Verma R, Larson E, Geis MC, Jassim AD. Primary cutaneous mantle cell lymphoma with blastic features: report of a rare case with special reference to staging and effectiveness of chemotherapy. J Cutan Pathol. 2012 Apr;39(4):449-53.

18 Cao Q, Li Y, Lin H, Ke Z, Liu Y, Ye Z. Mantle cell lymphoma of blastoid variant with skin lesion and rapid progression: a case report and literature review. Am J Dermatopathol. 2013 Dec;35(8):851-5.

19 Cesinaro AM, Bettelli S, Maccio L, Milani M. Primary cutaneous mantle cell lymphoma of the leg with blastoid morphology and aberrant immunophenotype: a diagnostic challenge. Am J Dermatopathol. 2014 Feb;36(2): e16-8.

20 Hrgovic I, Hartmann S, Steffen B, Vogl T, Kaufmann R, Meissner M. Cutaneous involvement as a rare first sign of systemic mantle cell lymphoma: a case report and review of the literature. Mol Clin Oncol. 2016 May; 4(5): 728-32.

21 Cherukuri AR, Kalia V, Sturtevant NV, DeStigter KK. Mantle cell lymphoma presenting as a subcutaneous soft tissue mass with an unusual appearance. Ultrasound Q. 2017 Mar;33(1):101-2.

22 Fakhri B, Kahl B. Current and emerging treatment options for mantle cell lymphoma. Ther Adv Hematol. 2017 Aug;8(8):223-34. 